\title{
Chapter 21 \\ Green Infrastructures in Megacity \\ Jakarta: Current Status and Possibilities \\ of Mangroves for Flood Damage \\ Mitigation
}

\author{
Yukichika Kawata
}

\begin{abstract}
Jakarta is Southeast Asia's most disaster-vulnerable city and recently has suffered from severe floods almost every year. Flood events have worsened mainly because of ground subsidence, reduction of green spaces, and littering into streams. The mangrove forests remaining in coastal urban areas of northern Jakarta can be utilized for mitigating flood damage. In the first two sections of this chapter, an overview of flood events is presented and the status of mangroves in Jakarta Bay is introduced. Mangroves may serve as hard and soft measures for disaster reduction. Because enlargement of the area of mangroves in urban Jakarta is difficult, in the last section, soft measures, especially the utilization of mangroves as an icon for disaster reduction, are proposed. Activities such as the incorporation of a mangrove design as a logo in documents of disaster prevention education may enhance citizens' recognition of disaster risks because they will see both logos and mangroves repeatedly in real life.
\end{abstract}

Keywords Floods · Icon for disaster reduction · Jakarta · Mangroves · Vulnerability

\subsection{Introduction}

Despite the high risk of natural disasters, people prefer to reside in coastal regions globally. Approximately $40 \%$ of the world's population is estimated to live within $100 \mathrm{~km}$ of the coast (United Nations 2017). In Indonesia, 65\% of people live in coastal areas (Ilman et al. 2011), where rapid population increase and economic development have been observed. The special capital region of Jakarta (hereafter referred to as Jakarta) is Southeast Asia's most populous city, and its population

\footnotetext{
Y. Kawata $(\bowtie)$

Faculty of Economics, Kindai University, Osaka, Japan

e-mail: ykawata@kindai.ac.jp
} 

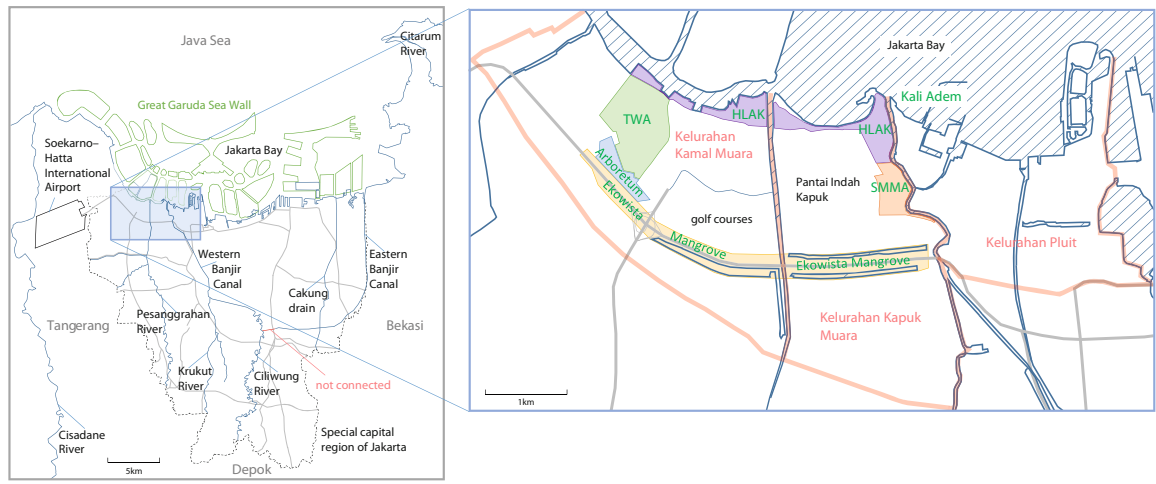

Fig. 21.1 Maps of Jakarta (left) and mangrove areas in Angke Kapuk (right)

size tripled in the past 50 years (Fig. 21.1). According to the Indonesian Disaster Database (DIBI), the majority of natural disasters are hydro-meteorological events (Badan Nasional Penanggulangan Bencana [BNPB] 2021). Based on the DIBI, flooding accounts for a large proportion of all disaster-related deaths $(28.0 \%)$, injuries $(37.6 \%)$, and houses destroyed $(35.2 \%)$ and evacuated $(95.5 \%)$ in Jakarta after 2000.

Natural disaster risk is the product of natural hazards, exposure, and vulnerability (United Nations Development Programme 2004). While the occurrence of natural hazards such as tsunami is uncontrollable, exposure is controllable but may not be in the short-term. A large number of poor and marginalized people settle in coastal areas of Asian countries (Pomeroy et al. 2006; Winsemius et al. 2018). In Jakarta, the poorest and most vulnerable people live in coastal areas illegally, and those under the most severe conditions suffer tidal flooding every day. They are reluctant to change settlements because of high land prices in safer places and good accessibility to their workplaces; they frequently return to these locales if they are forced into involuntary resettlement (Marschiavelli 2008; Padawangi 2012; Marfai et al. 2015). Vulnerability is the most controllable factor in present-day Jakarta, and hard and soft measures are applicable. Hard measures comprise artificial measures, including seawalls (gray infrastructures), and natural measures, including mangroves, which possess inherent coastal-disaster prevention functions (green infrastructures, GI) (Tanaka 2009; Nurhidayah and McIlgorm 2019), while soft measures minimize vulnerability through, for example, disaster prevention education.

Because many developing countries are located in tropical/subtropical regions, it is feasible to utilize GI, such as mangroves, coral reefs, and seagrass meadows, as ecological measures for disaster mitigation; this is referred to as Ecosystem-based Disaster Risk Reduction (Eco-DRR). By so doing, developing countries can ease the financial difficulty of constructing gray infrastructures (Esteban et al. 2017; Takagi 2019). Other advantages of GI include self-maintenance (Gedan et al. 2011) and self-repairing functions when damaged (Ferrario et al. 2014). Mangroves exert and enhance ecological resilience in coastal areas (Alongi 2008; Gilman et al. 2008; 
Takagi 2019). For example, mangroves can migrate in response to sea-level rise (SLR) and sustain coastal ecological resilience (Nyström and Folke 2001; Alongi 2008).

This chapter selects Jakarta as a coastal, highly-populated city with high vulnerability and reviews the current status and possibilities of urban mangroves in Jakarta Bay for natural disaster reduction. Currently, the range of mangrove habitat in urban Jakarta Bay is limited, and enlargement of habitat may be difficult. Therefore, this chapter also briefly discusses the potential role of mangroves as an icon in disaster prevention, that is, a kind of soft measure, utilizing mangroves as a visual cue for reminding the population of natural hazard risks.

\subsection{Floods in Jakarta}

\subsubsection{Most Vulnerable People}

Jakarta is located in the northwest of Java Island (Fig. 21.1). Population size has exceeded ten million. Thirteen rivers discharge into Jakarta Bay. The biggest are the Ciliwung and Cisadane rivers, and nine rivers are considered to be associated with floods (Marfai et al. 2015). Yusuf and Francisco (2009) provide a list of 132 vulnerable provinces in Southeast Asian countries, of which part of Jakarta's municipalities are ranked 1st (Central Jakarta), 2nd (North Jakarta), 3rd (West Jakarta), 5th (East Jakarta), and 8th (South Jakarta).

Globally, the poorest people are the most vulnerable to natural hazards (Esteban et al. 2013; Tauhid and Zawani 2018). In Jakarta, the poor gather in informal urban settlements called kampung, ${ }^{1}$ developed along, for example, riverbanks (Padawangi 2012), where people suffer from higher vulnerability than other urban residents (Firman et al. 2011; Arkema et al. 2013; Colven 2020). Jakarta's poor population was 0.373 million (3.57\%), and the percentage is the highest in North Jakarta (5.35\%) (Badan Pusat Statistik [BPS] 2018).

\subsubsection{Causes of Floods}

The frequency and magnitude of floods have been higher since the 2000s, and the 2007 flood was the worst in the past three centuries (Marfai et al. 2015; Colven 2020) (Fig. 21.2). The factors influencing the severity of floods are (1) heavy precipitation in the wet season, (2) SLR, (3) El Niño-Southern Oscillation (ENSO), (4) urbanization, and (5) accumulation of garbage in streams (Steinberg 2007;

\footnotetext{
${ }^{1}$ The term kampung is not a synonym for slum (Irawaty 2018) and does not necessarily consist of only poor people. However, kampung indicates the settlement of the poor in this chapter.
} 


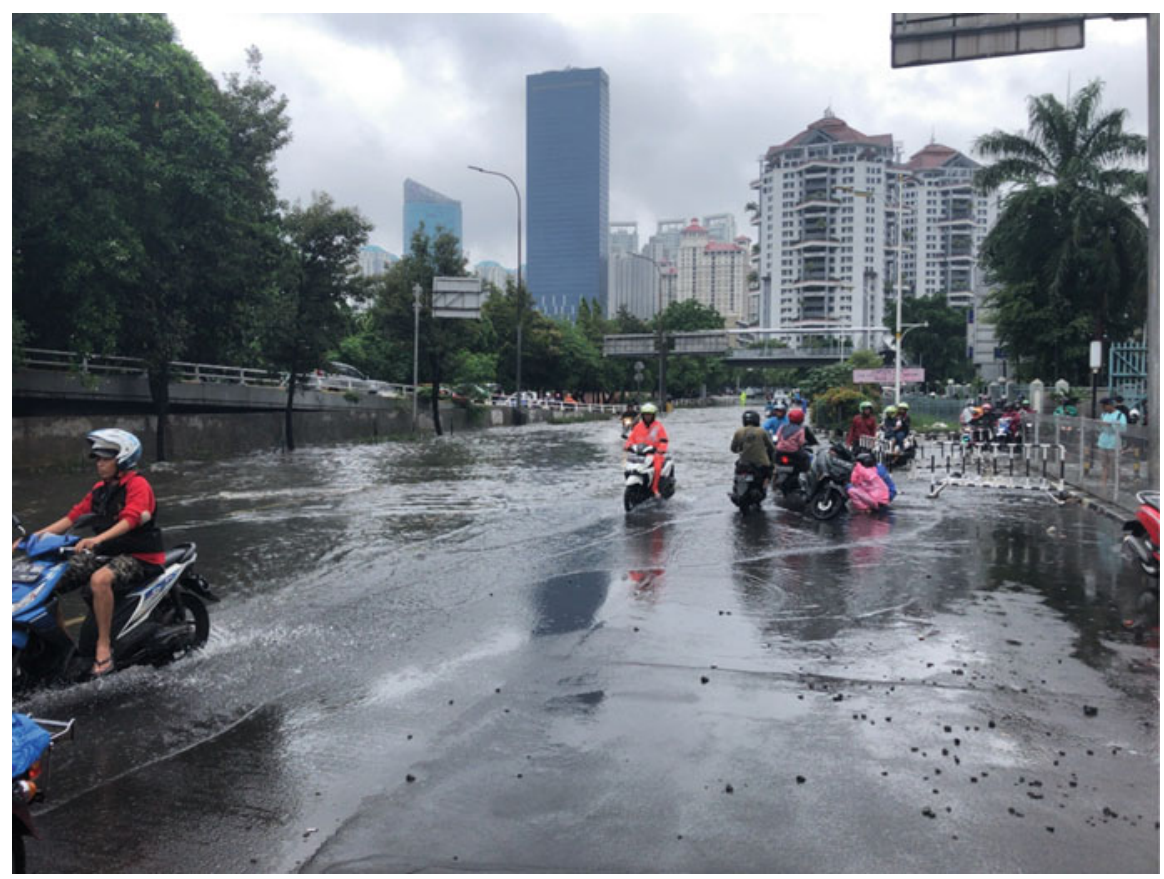

Fig. 21.2 Submerged roads near the Citraland Mall by the 2020 Jakarta Floods (taken by the author on January 1, 2020)

Marfai et al. 2015; Budiyono et al. 2016; Nurhidayah and McIlgorm 2019). The SLR in Jakarta coasts is $0.57 \mathrm{~cm} /$ year (Firman et al. 2011), which exacerbates flood damage in association with subsidence. The ENSO may also influence precipitation and inter-annual oscillations in sea surface height, causing more severe floods (Budiyono et al. 2016; Esteban et al. 2017; Takagi 2017).

Urbanization includes (4a) losses and degradations of urban lakes, called setu or situ, in the Ciliwung and Cisadane river watersheds (Henny and Meutia 2014), (4b) decrease of green areas and agricultural lands (Permatasari et al. 2016; Purwoko et al. 2016), and (4c) land subsidence. Approximately 10-20\% of urban lakes have been lost (Henny and Meutia 2014), and the green space ratio reduced from $40 \%$ in 1985 to $9 \%$ in 2002 (Steinberg 2007), which may increase surface runoff, facilitate land subsidence, and cause downstream inundation (Firman 2009). Subsidence is mainly attributed to groundwater extraction and is considered to be the most important factor affecting future flood events (Budiyono et al. 2016; Takagi et al. 2016b). The highest subsidence has observed near the coast at a rate up to 15-20 cm/year between 1995 and 2005 (Chaussard et al. 2013). Moreover, (4d) sedimentation of silt in the downstream has worsened the flood events (Colven 2020). 


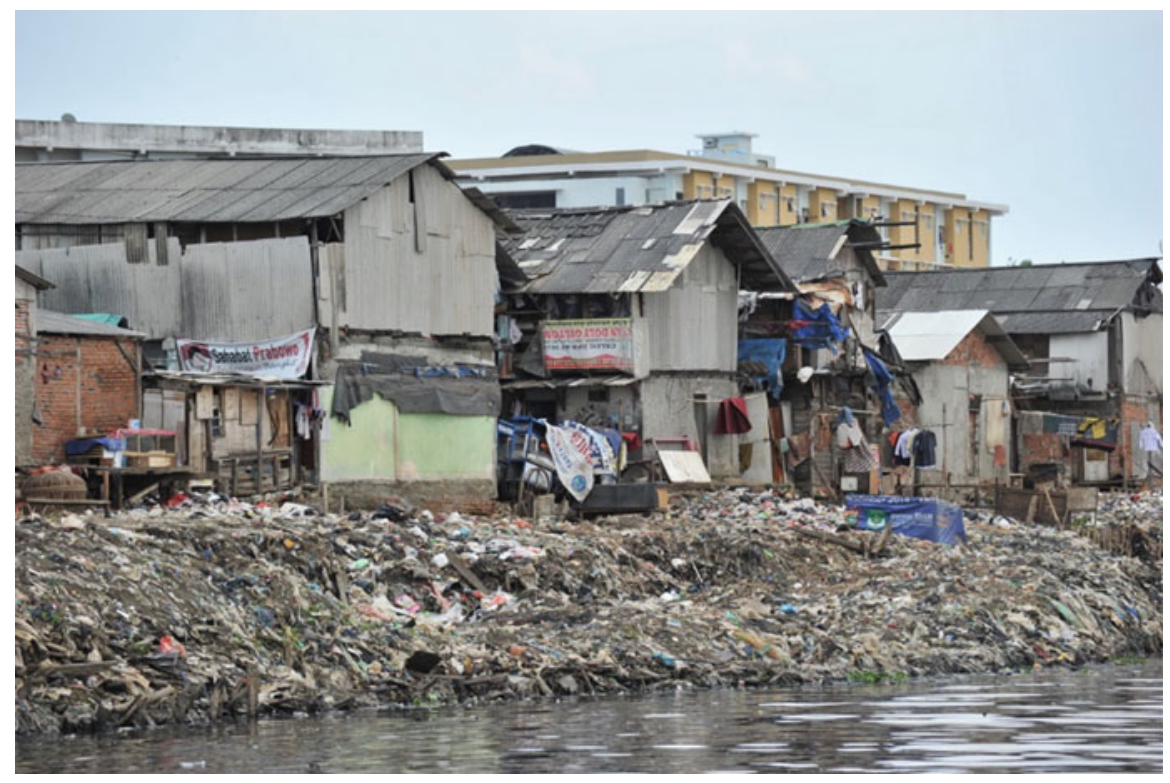

Fig. 21.3 Accumulation of garbage in Waduk Pluit (Pluit Reservoir, downstream of Ciliwung river) (taken by Dr. Hajime Matsushima on March 17, 2015)

Finally, (5) Jakarta has a long history of garbage dumping in canals and rivers from the age of Batavia (1619-1942) (Steinberg 2007), which reduces river flows (Fig. 21.3). Currently, 57.0-85.4\%, 8.1-31.4\%, and 0.4-19.9\% of wastes are from houses, industry, and livestock, respectively (Purwoko et al. 2016). The total volume of garbage discharged is $23,400 \mathrm{~m}^{3} / \mathrm{day}$, of which 14,700 are disposed by the City Sanitation Office, but some portion of the rest may be thrown into streams (Steinberg 2007). Furthermore, many do not receive garbage collection services (Colven 2020). Because riverbank settlers throw garbage into the river, the width of the Angke river was diminished from 40-60 $\mathrm{m}$ to 5-10 $\mathrm{m}$ (Steinberg 2007). A large proportion of rainwater from upstream contains garbage and may worsen downstream floods (Purwoko et al. 2016).

\subsubsection{Current Countermeasures}

Some countermeasures have been implemented. First, river dredging and expansion have been conducted as river normalization projects (Colven 2017, 2020). A flood canal, called Western Banjir Canal (WBC), was constructed and connected to the downstream of the Ciliwung river in the early twentieth century. The Eastern Banjir Canal (EBC) was developed to further mitigate floods and was utilized after 2011, but the plan to connect the WBC and EBC remains unrealized (the part indicated 


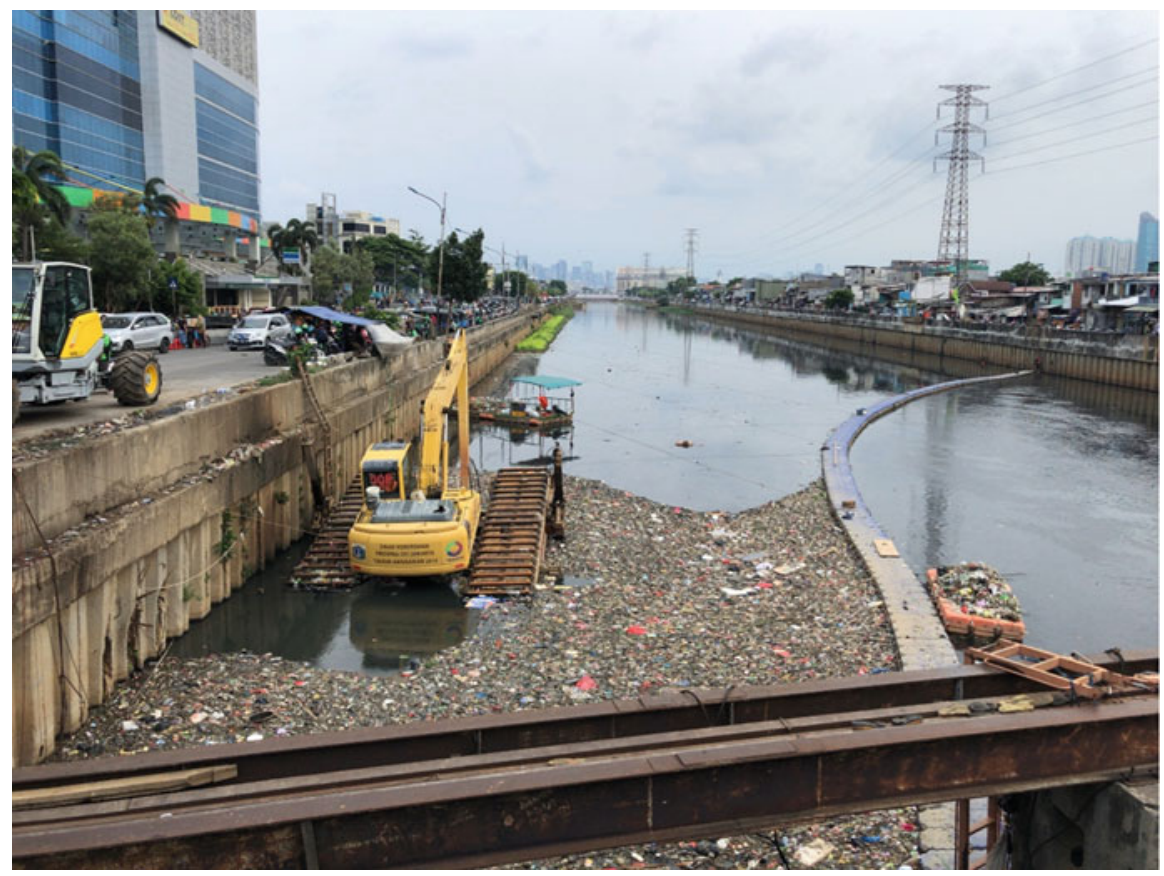

Fig. 21.4 River cleaning activities by local government in Western Banjir Canal (downstream of the Ciliwung river) near the Seasons City Trade Mall (taken by the author on November 30, 2019)

by a red line in the left-hand chart of Fig. 21.1). Second, the central government plans to make Ciawi and Sukamahi retention basins in Bogor district to reduce the water volume of the Ciliwung river. Third, the National Capital Integrated Coastal Development program is ongoing, which includes the construction of the Great Garuda Sea Wall (GGSW, $32 \mathrm{~km}$ ) in the gulf of Jakarta and the construction of artificial islands, including one with the shape of Garuda ${ }^{2}$ (more than 1000 ha) (Colven 2017; Nurhidayah and McIlgorm 2019). The construction of GGSW is controversial because it may cause damage to coastal fisheries and mangroves and does not mitigate subsidence (Colven 2017).

Other activities include the removal of waste and trash from rivers and canals by Jakarta's Public Facility Maintenance Agency (Figs. 21.4 and 21.5). Local communities also conduct river and canal cleaning voluntarily (Marschiavelli 2008; Marfai et al. 2015; Purwoko et al. 2016). In coastal and riverside kampung, people living in single-storied houses add a second floor as a place of refuge (Marschiavelli 2008; Marfai et al. 2015; Budiyono et al. 2016; Wijayanti et al. 2017). Takagi et al. (2016a) recommend escaping to the second floor rather than moving long distances to higher places when dykes break. Some people in Kali Adem, a coastal

\footnotetext{
${ }^{2}$ A legendary bird used in the Indonesian national emblem.
} 


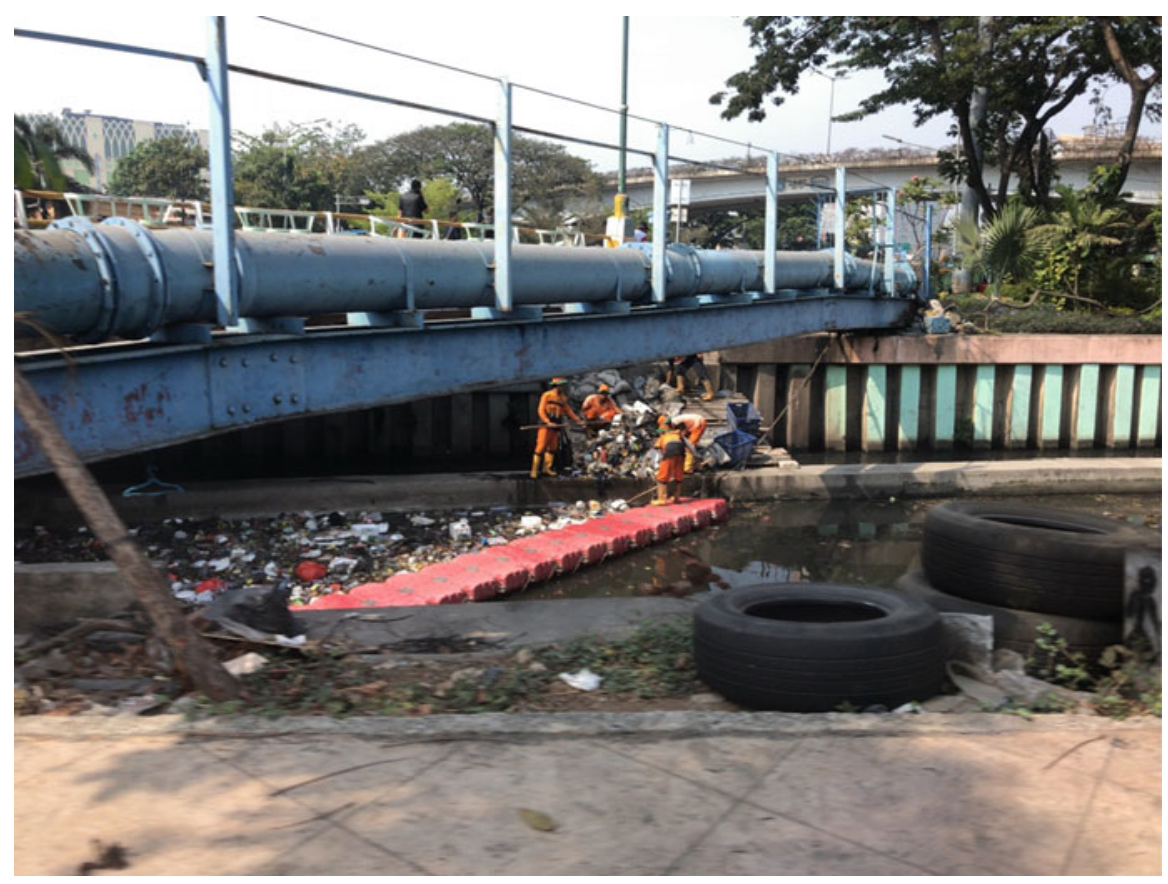

Fig. 21.5 River cleaning activities by pasukan orange (orange troops) of the Jakarta's Public Facility Maintenance Agency at Saluran Cideng (Cideng waterway) (taken by the author on October 4, 2019)

village, elect to live in fishing boats to avoid floods (Padawangi 2012). Some local communities utilize mosques as evacuation sites (Marfai et al. 2015).

\subsection{Mangroves in the Gulf of Jakarta}

\subsubsection{Recognition of Mangroves as GI in Indonesia}

The advantage of GI is gradually being acknowledged in Indonesia. The 1992 Flores Island Earthquake Tsunami highlighted the bio-shield function of mangroves in Indonesia (Karminarsih 2007). After the 2004 Aceh Tsunami, Indonesians recognized the term tsunami much more (Baeda et al. 2015) and became more aware of mangrove's Eco-DRR function (Karminarsih 2007). The Indonesian government tried to create a green belt on the Banda Aceh coast after the 2004 Aceh Tsunami, although it remains incomplete (Dalimunthe 2018). Simultaneously, the Minister of Forestry launched a plan to reforest 600 thousand hectares of depleted mangroves (Barbier 2008). The government proclaimed the National Strategy for Mangrove Ecosystem Management (Indonesian Government 2012). Mangrove rehabilitation 
program Ayo Tanam Mangrove (Let's Plant Mangrove) has been implemented nationwide by the Ministry of Fisheries and Marine Affairs for more than a decade, and mangrove afforestation is regarded as a prospective way of improving Eco-DRR in Indonesia (Dalimunthe 2018).

\subsubsection{Functions and Status of Mangroves}

Mangroves are a group of halophytic plants inhabiting the intertidal zone of tropical and subtropical regions. Giri et al. (2011) estimate the world's mangrove area is $137,760 \mathrm{~km}^{2}$ in 2000 , of which $22.6 \%\left(31,130 \mathrm{~km}^{2}\right)$ is in Indonesia. Indonesian mangroves are distinguished by having the largest number of species and the largest area (Ilman et al. 2011), but about 30\% of their area has been lost since 1980 (Giesen et al. 2006; Murdiyarso et al. 2015) mainly because of transformation to shrimp ponds (63\%) and agricultural lands (32\%) (Giri et al. 2008).

Mangroves may protect coastal areas from tsunamis, tidal surges, floods, and cyclones (or typhoons, hurricanes) by mitigating waves and winds and minimize damage to property and human life (e.g., Danielsen et al. 2005; Kathiresan 2012; Unnikrishnan et al. 2013; Sandilyan and Kathiresan 2015). Some types of mangroves have prop roots or pneumatophores, which strengthen their durability against winds and facilitate the accretion of sediment, resulting in wave attenuation (Alongi 2008; Ostling et al. 2009). Accumulation of sediment preserves or even expands the coastline (Marois and Mitsch 2015). The sturdy trunks and extensive root complexes of mangroves, along with accumulated sediments, mitigate the speed of flood, and sediments also absorb floodwater (Ilman et al. 2011). Moreover, mangroves mitigate the impact of dyke-breaking tsunamis, a kind of flooding "caused by the rupture of a coastal dyke" (Takagi et al. 2016a, p. 1630). People may save their lives from tidal waves by climbing, clinging to, or hanging in mangrove trees (Forbes and Broadhead 2007; Sandilyan and Kathiresan 2015).

\subsubsection{Mangroves in North Jakarta}

The most famous and extensively examined mangroves in Jakarta Bay are Mangrove Angke Kapuk (MAK) in Kelurahan Kamal Muara (Kamal Muara village) and Kelurahan Kapuk Muara (Kapuk Muara village) of Kecamatan Penjaringan (Penjaringan district) (Fig. 21.6; right-hand chart of Fig. 21.1). The MAK consists of mangrove forests in (1) Hutan Lindung Angke Kapuk (HLAK, Angke Kapuk protected forest, 44.76 ha), (2) Taman Wisata Alam (TWA, Angke Kapuk national park, 99.82 ha), (3) Arboretum (10.51 ha), (4) Suaka Margasatwa Muara Angke (SMMA, Muara Angke Wildlife Reserve, 25.02 ha), and (5) Ekowista Mangrove (95.50 ha) (Kusmana et al. 2013). There are 11 true (exclusive) mangroves in MAK, and the dominant species are Avicennia spp. and Rhizophora spp. (Pambudi et al. 


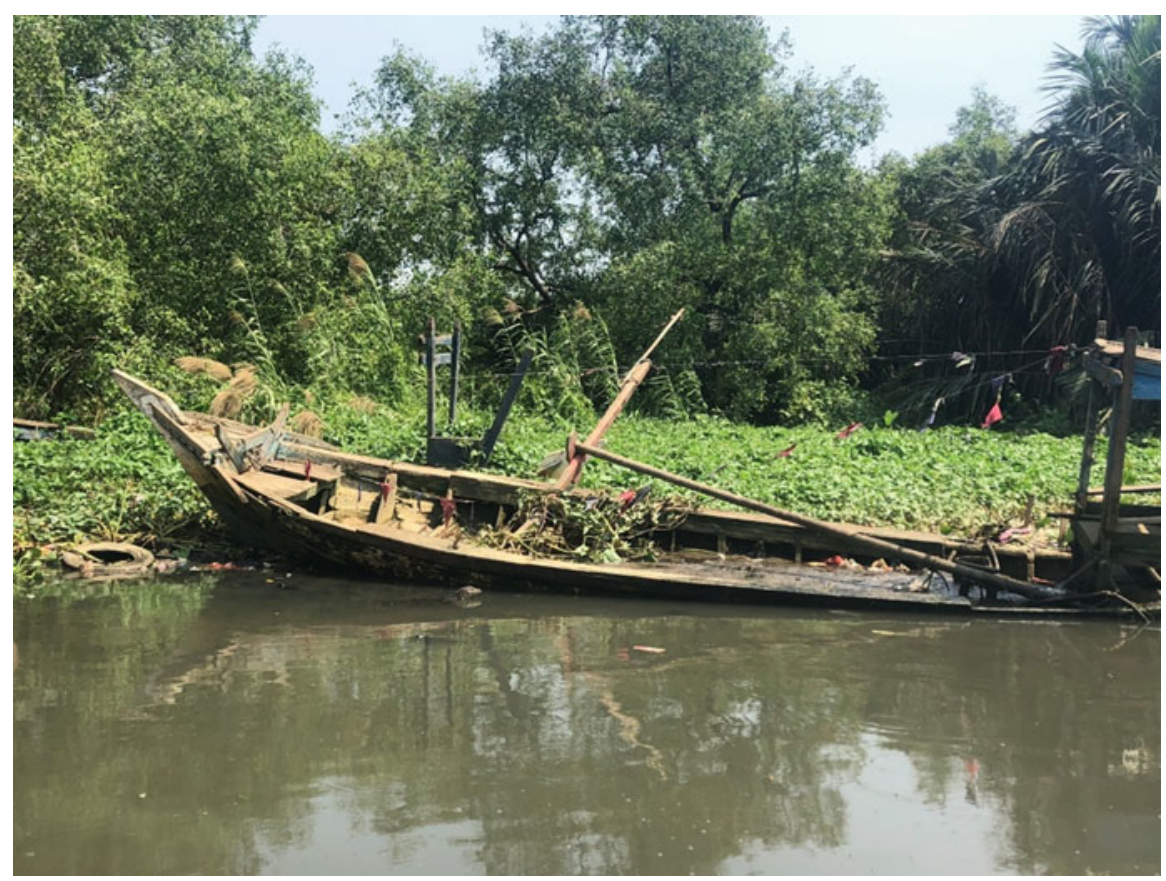

Fig. 21.6 Riparian forests in HLAK (taken by Dr. Emma Colven on May 25, 2019)

2018). Some residential areas including Pantai Indah Kapuk (PIK), a relatively wealthy area, and golf courses are also located near the MAK. The east side of the MAK is Kelurahan Pluit (Pluit village), which is another village of Penjaringan district and contains mangrove forest (6) Kali Adem.

The total mangrove area in Jakarta has decreased from 1165.33 ha in 1980 to 165.28 ha in 2016 (Hilmi et al. 2017). Mangroves in Angke Kapuk and adjacent areas have been transformed into residential and industrial areas, highways, an airport, and fish ponds since the late 1970s (Ambinari et al. 2016; Kusmana 2017). Wastes and pollutants from upstream and residential areas in MAK are also significant factors of mangrove degradation (Hilmi et al. 2017; Sofian et al. 2020). One of the main wastes is plastic debris in MAK (Cordova and Nurhati 2019; Sofian et al. 2020), mostly polystyrene (44.62\%), a polymer used for food packaging (Purwoko et al. 2016; Cordova et al. 2021). Plastic debris prevents air uptake by pneumatophores (Purwoko et al. 2016) and reduces the strength of mangrove roots (Sofian et al. 2020) and interferes with mangrove regeneration by inhibiting the growth of seeds (Sasongko et al. 2014; Putri et al. 2015). Other pollutants, including heavy metals, nitrogen, and phosphorus, affect some sorts of mangroves (Hamzah and Setiawan 2010; Ambinari et al. 2016; Purwoko et al. 2016; Pambudi et al. 2018). Furthermore, groundwater extraction, land subsidence, and associated changes of hydrological conditions may result in the loss of mangroves (Gilman et 
al. 2008; Ilman et al. 2016). Because of waste accumulation and pollution, mangrove diversity diminishes (Sasongko et al. 2014; Putri et al. 2015), and those tolerant to pollution such as Avicennia marina and Rhizophora mucronata dominate in the MAK (Wibowo 2006; Pambudi et al. 2018).

Several mangrove rehabilitation projects have been implemented in HLAK (Penyusun 2009; Sasongko et al. 2014), Jakarta Fishing Port in Pluit village (Takagi et al. 2016a), and Kali Adem (Rahadian et al. 2019). The rehabilitation at HLAK is conducted by a group Sahabat Bakau (Friends of Mangrove). They have constructed 1780 -m-long stone breakwater, $100 \mathrm{~m}$ from the coast, and 8000 mangroves were planted (Penyusun 2009).

Mangrove degradation causes significant $\mathrm{CO}_{2}$ emissions (Kathiresan 2012; Murdiyarso et al. 2015; Sandilyan and Kathiresan 2015) and the loss of natural disaster mitigation (Gilman et al. 2008; Giri et al. 2008). For example, the PIK was formerly a mangrove forest able to store excess rainfall and high tides, but this water storage function was lost, and the number of floods increased; thus, the toll road surface (roads go through the Ekowista Mangrove in Fig. 21.1) was raised by $1.2 \mathrm{~m}$ to prevent flood impacts (Ilman et al. 2011). Removal of mangroves also caused the loss of coastal sediments (Penyusun 2009).

\subsection{Possibilities of Mangroves for Flood Damage Mitigation}

To address Jakarta's current issues, including floods, subsidence, and loss of greenery (Sasongko et al. 2014), rehabilitation of mangroves is recommended, but suitable areas are limited. The most realistic option might be to conserve current mangroves in an appropriate state while emphasizing soft measures more. In this section, requirements and limitations of rehabilitation are summarized, and potential mangrove functions as soft measures are discussed.

\subsubsection{Hard Measures: Rehabilitation of Mangroves for GI}

Several points should be noted in promoting the restoration of mangroves. A minimum width or area is required to sustain mangroves, to maintain species richness, and to support the provision of ecosystem services (Duke et al. 2007; Ilman et al. 2011; McIvor et al. 2012). There is controversy as to whether urban and aquacultural areas can be restored to mangroves (Giri et al. 2008; Biswas et al. 2009; van Oudenhoven et al. 2015), and if a suitable area is not fully secured, mangroves may not exert tidal attenuation function (Takagi 2017). Locations of restored mangroves are critical for disaster reduction. Mangroves reduce the rate of fatalities of a tsunami when they are located in front of residential areas (Danielsen et al. 2005) but escalate damage when settled areas are located between the coast and mangrove forest (Bayas et al. 2011). Another restriction is coastal squeeze, 
which happens because of SLR and urbanization. Belize's example demonstrates that mangroves need to move landward $500 \mathrm{~m}$ for $1 \mathrm{~m}$ SLR (Guannel et al. 2016), but expansion inland is limited by many factors, including the presence of a developed land surface (Gilman et al. 2008; Pontee 2013; Marois and Mitsch 2015). Other conditions, including water depth and contamination level, may also be restrictive (Sasongko et al. 2014; Putri et al. 2015; Takagi et al. 2016a; Takagi 2019). Mangroves located in creeks, estuaries, and inlets may increase the height of a tsunami and accelerate the flow, resulting in more severe damage (Forbes and Broadhead 2007; Tanaka 2009; Power 2013).

Existing studies highlight the importance of considering biological diversity (Tanaka 2009; Takagi 2019), original vegetation (Karminarsih 2007; Purwoko et al. 2016), species that have a high tolerance of floods (Alongi 2008) and tsunamis (Kathiresan and Rajendran 2005; Tanaka 2009; Yanagisawa et al. 2009), and a mangrove landscaping strategy that effectively reduces the impacts of tsunamis and high waves (Hilmi 2018). Because polluted sediments and floating garbage may hinder the growth of mangroves, species with high tolerance to these factors are recommended (Putri et al. 2015; Pambudi et al. 2018). The most promising species for disaster prevention are Avicennia marina for floods (Alongi 2008) and Rhizophora spp. for tsunami (Kathiresan and Rajendran 2005; Yanagisawa et al. 2009), which dominate the MAK.

The current status of contamination and urbanization may be restrictive to any substantial improvement in mangrove diversity and area. A more promising idea may be to combine mangrove improvements with other remedies. Groundwater regulations contribute to diminishing subsidence and flood events (Budiyono et al. 2016; Esteban et al. 2017), although similar regulations have already been implemented in Jakarta, but in an unsatisfactory manner. Multiple lines of defense (Lopez 2009), whereby the coast is protected by a combination of seascape elements, including coral reefs, seagrass meadows, and mangroves (Guannel et al. 2016), attracts the attention of practitioners (Arkema et al. 2017) because multiple lines of defense may exert more disaster prevention functions (Barbier 2016; Guannel et al. 2016), along with the provision of varied ecological services, and establish a solid environmental complex.

\subsubsection{Soft Measures: Mangroves as a Disaster Prevention Icon}

Mangroves can be utilized more when applying soft measures for disaster reduction. The MAK may serve as an icon, similar to the panda used by the World Wide Fund for Nature as its icon or logo. In multiple activities involving citizens, authorities can utilize mangroves as an iconic cue to make citizens think of vulnerability to natural disasters and the necessity to stop littering. 
First, risk-mitigating actions, including early-warning systems and disaster prevention education, should be emphasized more (Bayas et al. 2011; Marois and Mitsch 2015), and designs with mangroves could be adopted in documents of such disaster prevention initiatives. Some victims of the 2006 Java Tsunami did not flee to safer places when they saw the telltale drawdown because of a lack of disaster prevention education and early-warning systems (Kerr and Andrew 2007). Regardless of the existence of gray infrastructures, including concrete dikes, too much expectation for GI may lead to loss of life (Dahdouh-Guebas et al. 2005). Multiple malls scattered in Jakarta (Steinberg 2007) may serve as evacuation areas. Special consideration for those in kampung is necessary because they suffer floods every week (Marfai et al. 2015; Esteban et al. 2017; Colven 2020) and tend to underestimate their vulnerability. One feasible way of enhancing kampung residents' disaster prevention activities includes participation in mangrove rehabilitation programs, which may also improve their knowledge of disaster prevention. $^{3}$ Tanaka (2009) states that vegetated areas such as mangroves can be used in disaster prevention education by local temples or local authorities. Because Indonesians regularly hold religious meetings, reduction of littering and improvement of disaster prevention knowledge through education are feasible. The iconic mangroves, printed in educational materials, may enhance participants' recognition when used repeatedly.

Second, because deforestation of mangroves causes sedimentation of creeks, canals, and estuaries (Wolanski et al. 1992) and increases flood events, mangroves can be planted along upstream riverbanks. Riparian mangrove forests can also be utilized as an icon of disaster prevention for local residents.

Acknowledgments The author is grateful for constructive comments on an earlier version of the manuscript, especially from Futoshi Nakamura and Hajime Matsushima. The author also thanks Emma Colven and H. Matsushima for providing pictures.

\section{References}

Alongi DM (2008) Mangrove forests: resilience, protection from tsunamis, and responses to global climate change. Estuar Coast Shelf Sci 76:1-13. https://10.1016/j.ecss.2007.08.024

Ambinari M, Darusman D, Alikodra HS, Santoso N (2016) Penataan peran para pihak dalam pengelolaan hutan mangrove di perkotaan: Studi kasus pengelolaan hutan mangrove di teluk Jakarta. Jurnal Analisis Kebijakan Kehutanan 13(1):29-40. https://doi.org/10.20886/ jakk.2016.13.1.29-40

Arkema KK, Guannel G, Verutes G, Wood SA, Guerry A, Ruckelshaus M, Kareiva P, Lacayo M, Silver JM (2013) Coastal habitats shield people and property from sea-level rise and storms. Nature Clim Change 3:913-918. https://doi.org/10.1038/nclimate1944

\footnotetext{
${ }^{3}$ To promote their participation, benefits, including the assignment of some rights, such as mangrove ownership (Biswas et al. 2009), financial payment for participation (Karminarsih 2007; Sasongko et al. 2014), and reflection of their opinion in rehabilitation programs (Padawangi 2012; Dalimunthe 2018; Martínez-Espinosa et al. 2020), should be emphasized more.
} 
Arkema KK, Griffin R, Maldonado S, Silver J, Suckale J, Guerry AD (2017) Linking social, ecological, and physical science to advance natural and nature-based protection for coastal communities. Ann N Y Acad Sci 1399:5-26. https://doi.org/10.1111/nyas.13322

Baeda AY, Suriamihardja DA, Umar H, Rachman T (2015) Tsunami mitigation plan for Manakarra Beach of West Sulawesi Province, Indonesia. Procedia Engineering 116:134-140. https:// doi.org/10.1016/j.proeng.2015.08.274

Barbier EB (2008) In the wake of tsunami: lessons learned from the household decision to replant mangroves in Thailand. Resour Energy Econ 30:229-249. https://doi.org/10.1016/ j.reseneeco.2007.08.002

Barbier EB (2016) The protective service of mangrove ecosystems: a review of valuation methods. Mar Pollut Bull 109:676-681. https://doi.org/10.1016/j.marpolbul.2016.01.033

Bayas JCL, Marohn C, Dercon G, Dewi S, Piepho HP, Joshi L, van Noordwijk M, Cadisch G (2011) Influence of coastal vegetation on the 2004 tsunami wave impact in West Aceh. Proc Natl Acad Sci 108(46):18612-18617. https://doi.org/10.1073/pnas.1013516108

Biswas SR, Mallik AU, Choudhury JK, Nishat A (2009) A unified framework for the restoration of southeast Asian mangroves-bridging ecology, society and economics. Wetl Ecol Manag 17:365-383. https://doi.org/10.1007/s11273-008-9113-7

Badan Nasional Penanggulangan Bencana [BNPB] (2021) Data dan Informasi Bencana Indonesia. Retrieved March 2, 2021, from http://dibi.bnpb.go.id/

Badan Pusat Statistik [BPS] (2018) Data dan informasi kemiskinan kabupaten/kota tahun 2018. Retrieved March 8, 2021, from https://www.bps.go.id/publication/

Kabupaten/Kota Tahun (2018). Retrieved March 8, 2021, from https://www.bps.go.id/publication/

Budiyono Y, Aerts JCJH, Tollenaar D, Ward PJ (2016) River flood risk in Jakarta under scenarios of future change. Nat Hazards Earth Syst Sci 16:757-774. https://doi.org/10.5194/nhess-16$757-2016$

Chaussard E, Amelung F, Abidin H, Hong S-H (2013) Sinking cities in Indonesia: ALOS PALSAR detects rapid subsidence due to groundwater and gas extraction. Remote Sens Environ 128:150 161. https://doi.org/10.1016/j.rse.2012.10.015

Colven E (2017) Understanding the allure of big infrastructure: Jakarta's great Garuda Sea wall project. Water Alternatives 10(2):250-264

Colven E (2020) Subterranean infrastructures in a sinking city: the politics of visibility in Jakarta. Crit Asian Stud 52(3):311-331. https://doi.org/10.1080/14672715.2020.1793210

Cordova MR, Nurhati IS (2019) Major sources and monthly variations in the release of landderived marine debris from the greater Jakarta area, Indonesia. Sci Rep 9:18730. https://doi.org/ 10.1038/s41598-019-55065-2

Cordova MR, Ulumuddin YI, Purbonegoro T, Shiomoto A (2021) Characterization of microplastics in mangrove sediment of Muara Angke wildlife reserve, Indonesia. Mar Pollut Bull 163:112012. https://doi.org/10.1016/j.marpolbul.2021.112012

Dahdouh-Guebas F, Jayatissa LP, Di Nitto D, Bosire JO, Lo Seen D, Koedam N (2005) How effective were mangroves as a defence against the recent tsunami? Curr Biol 15(12):R443R447. https://doi.org/10.1016/j.cub.2005.06.008

Dalimunthe SA (2018) Who manages space? Eco-DRR and the local community. Sustainability 10:1705. https://doi.org/10.3390/su10061705

Danielsen F, Sorensen MK, Olwig MF, Selvam V, Parish F, Burgess ND, Hiraishi T, Karunagaran VM, Rasmussen MS, Hansen LB, Quarto A, Suryadiputra N (2005) The Asian tsunami: a protective role for coastal vegetation. Science 320(5748):643. https://doi.org/10.1126/ science. 1118387

Duke NC, Meynecke J-O, Dittmann S, Ellison AM, Anger K, Berger U, Cannicci S, Diele K, Ewel KC, Field CD, Koedam N, Lee SY, Marchand C, Nordhaus I, Dahdouh-Guebas F (2007) A world without mangroves? Science 317(5834):41-42. https://10.1126/science.317.5834.41b

Esteban M, Tsimopoulou V, Mikami T, Yun NY, Suppasri A, Shibayama T (2013) Recent tsunamis events and preparedness: development of tsunami awareness in Indonesia, Chile and Japan. International Journal of Disaster Risk Reduction 5:84-97. https://doi.org/10.1016/ j.ijdrr.2013.07.002 
Guannel G, Arkema K, Ruggiero P, Verutes G (2016) The power of three: coral reefs, seagrasses and mangroves protect coastal regions and increase their resilience. PLoS One 11(7):e0158094. https://doi.org/10.1371/journal.pone.0158094

Esteban M, Takagi H, Mikami T, Aprilia A, Fujii D, Kurobe S, Utama NA (2017) Awareness of coastal floods in impoverished subsiding coastal communities in Jakarta: tsunamis, typhoon storm surges and dyke-induced tsunamis. International Journal of Disaster Risk Reduction 23:70-79. https://doi.org/10.1016/j.ijdrr.2017.04.007

Ferrario F, Beck MW, Storlazzi CD, Micheli F, Shepard CC, Airoldi L (2014) The effectiveness of coral reefs for coastal hazard risk reduction and adaptation. Nat Commun 5:3794. https:// doi.org/10.1038/ncomms4794

Firman $T$ (2009) The continuity and change in mega-urbanization in Indonesia: a survey of Jakarta-Bandung region (JBR) development. Habitat Int 33(4):327-339. https://doi.org/ 10.1016/j.habitatint.2008.08.005

Firman T, Surbakti IM, Idroes IC, Simarmata HA (2011) Potential climate-change related vulnerabilities in Jakarta: challenges and current status. Habitat Int 35(2):372-378. https:// doi.org/10.1016/j.habitatint.2010.11.011

Forbes, K. \& Broadhead, J. (2007). The role of coastal forests in the mitigation of tsunami impacts. RAP PUBLICATION 2007/1. Food and Agriculture Organization of the United Nations Regional Office for Asia and the Pacific. Bangkok. Retrieved September 4, 2020, from http://www.fao.org/forestry/14561-09bf06569b748c827dddf4003076c480c.pdf

Gedan KB, Kirwan ML, Wolanski E, Barbier EB, Silliman BR (2011) The present and future role of coastal wetland vegetation in protecting shorelines: answering recent challenges to the paradigm. Clim Chang 106:7-29. https://doi.org/10.1007/s10584-010-0003-7

Giesen W, Wulffraat S, Zieren M, Scholten L (2006) Mangrove guide book for Southeast Asia. FAO and Wetlands International

Gilman EL, Ellison J, Duke NC, Field C (2008) Threats to mangroves from climate change and adaptation options: a review. Aquat Bot 89(2):237-250. https://doi.org/10.1016/ j.aquabot.2007.12.009

Giri C, Zhu Z, Tieszen LL, Singh A, Gillette S, Kelmelis JA (2008) Mangrove forest distributions and dynamics (1975-2005) of the tsunami-affected region of Asia. J Biogeogr 35:519-528. https://doi.org/10.1111/j.1365-2699.2007.01806.x

Giri C, Ochieng E, Tieszen LL, Zhu Z, Singh A, Loveland T, Masek J, Duke N (2011) Status and distribution of mangrove forests of the world using earth observation satellite data. Glob Ecol Biogeogr 20:154-159. https://doi.org/10.1111/j.1466-8238.2010.00584.x

Hamzah F, Setiawan A (2010) Akumulasi logam berat $\mathrm{Pb}, \mathrm{Cu}$, dan $\mathrm{Zn}$ di hutan mangrove Muara Angke, Jakarta Utara. Jurnal Ilmu dan Teknologi Kelautan Tropis 2(2):41-52

Henny C, Meutia AA (2014) Urban Lakes in megacity Jakarta: risk and management plan for future sustainability. Procedia Environ Sci 20:737-746. https://doi.org/10.1016/j.proenv.2014.03.088

Hilmi E, Kusmana C, Suhendang E, Iskandar (2017) Correlation analysis between seawater intrusion and mangrove greenbelt. Indonesian Journal of Forestry Research 4(2):151-168. https://doi.org/10.20886/ijfr.2017.4.2

Hilmi E (2018) Mangrove landscaping using the modulus of elasticity and rupture properties to reduce coastal disaster risk. Ocean \& Coastal Management 165:71-79. https://doi.org/10.1016/ j.ocecoaman.2018.08.002

Ilman M, Wibisono ITC, Suryadiputra INN (2011) State of the art information on mangrove ecosystems in Indonesia. (translated by Suryadiputra, W.) technical report. https://doi.org/ 10.13140/RG.2.1.3967.9120

Ilman M, Dargusch P, Dart P, Onrizal (2016) A historical analysis of the drivers of loss and degradation of Indonesia's mangroves. Land Use Policy 54:448-459. https://doi.org/10.1016/ j.landusepol.2016.03.010

Indonesian Government (2012) Peraturan Presiden Republik Indonesia Nomor 73 Tahun 2012 tentang Strategi Nasional Pengelolaan Ekosistem Mangrove. Retrieved March 2, 2021, from http://dishut.jabarprov.go.id/data/menu/PP73tahun2012.pdf 
Irawaty DT (2018) Jakarta's Kampungs: their history and contested future. Retrieved June 14, 2021, from https://escholarship.org/uc/item/55w9b9g

Karminarsih E (2007) Pemanfaatan Ekosistem Mangrove bagi Minimasi Dampak Bencana di Wilayah Pesisir. Jurnal Manajemen Hutan Tropika 13(3):182-187

Kathiresan K (2012) Importance of mangrove ecosystem. International Journal of Marine Science 2(10):70-89. https://doi.org/10.5376/ijms.2012.02.0010

Kathiresan K, Rajendran N (2005) Coastal mangrove forests mitigated tsunami. Estuar Coast Shelf Sci 65(3):601-606. https://doi.org/10.1016/j.ecss.2005.06.022

Kerr AM, Andrew H (2007) Natural barriers to natural disasters. Bioscience 57(2):102-103. https:/ /doi.org/10.1641/B570202

Kusmana C, Valentino N, Mulyana D (2013) Ensiklopedia Flora Mangrove di Kawasan Hutan Angke Kapuk. Sahabat Bakau

Kusmana C (2017) Lesson learned from mangrove rehabilitation program in Indonesia. Jurnal Pengelolaan Sumberdaya Alam dan Lingkungan 7(1):89-97. https://doi.org/10.19081/ jpsl.2017.7.1.89

Lopez JA (2009) The multiple lines of defense strategy to sustain coastal Louisiana. J Coast Res 54:186-197. http://www.jstor.org/stable/25737479

Marfai MA, Sekaranom AB, Ward P (2015) Community responses and adaptation strategies toward flood hazard in Jakarta, Indonesia. Nat Hazards 75:1127-1144. https://doi.org/10.1007/s11069014-1365-3

Marois DE, Mitsch WJ (2015) Coastal protection from tsunamis and cyclones provided by mangrove wetlands - a review. International Journal of Biodiversity Science, Ecosystem Services \& Management 11(1):71-83. https://doi.org/10.1080/21513732.2014.997292

Marschiavelli MIC (2008) Vulnerability assessment and coping mechanism related to floods in urban areas: a community-based case study in kampung Melayu. Gadjah Mada University, Indonesia. Retrieved January 19, 2021, from https://webapps.itc.utwente.nl/librarywww/ papers_2008/msc/ugm/marschiave.pdf

Martínez-Espinosa C, Wolfs P, Velde KV, Satyanarayana B, Dahdouh-Guebasa F, Hugé J (2020) Call for a collaborative management at Matang mangrove Forest reserve, Malaysia: an assessment from local stakeholders' view point. For Ecol Manag 458:117741. https://doi.org/ 10.1016/j.foreco.2019.117741

McIvor AL, Möller I, Spencer T, Spalding M (2012) Reduction of wind and swell waves by mangroves. Natural coastal protection series: report 1. Cambridge coastal research unit working paper 40. Retrieved March 12, 2021, from http://www.naturalcoastalprotection.org/documents/ reduction-of-wind-and-swell-waves-by-mangroves

Murdiyarso D, Purbopuspito J, Kauffman JB, Warren MW, Sasmito SD, Donato DC, Manuri S, Krisnawati H, Taberima S, Kurnianto S (2015) The potential of Indonesian mangrove forests for global climate change mitigation. Nat Clim Chang 5(12):1089-1092. https://doi.org/10.1038/ NCLIMATE2734

Nurhidayah L, McIlgorm A (2019) Coastal adaptation laws and the social justice of policies to address sea level rise: an Indonesian insight. Ocean \& Coastal Management 171:11-18. https:/ /doi.org/10.1016/j.ocecoaman.2019.01.011

Nyström M, Folke C (2001) Spatial resilience of coral reefs. Ecosystems 4(5):406-417. http:// www.jstor.org/stable/3658801

Ostling JL, Butler DR, Dixon RW (2009) The biogeomorphology of mangroves and their role in natural hazards mitigation. Geogr Compass 3(5):1607-1624. https://doi.org/10.1111/j.17498198.2009.00265.x

van Oudenhoven APE, Siahainenia AJ, Sualia I, Tonneijck FH, van der Ploeg S, de Groot RS, Alkemade R, Leemans R (2015) Effects of different management regimes on mangrove ecosystem services in Java, Indonesia. Ocean \& Coastal Management 116:353-367. https:// doi.org/10.1016/j.ocecoaman.2015.08.003 
Padawangi R (2012) Climate change and the north coast of Jakarta: environmental justice and the social construction of space in urban poor communities. In: Holt WG (ed) Urban areas and global climate change. Emerald Group Publishing Limited, Bingley, pp 321-339. https:// doi.org/10.1108/S1047-0042(2012)0000012016

Pambudi AC, Gusviga BH, Fahrezi ZA (2018) Analysis of mangrove forest change in Muara Angke Jakarta by using geographical information system and remote sensing. Prosiding Seminar Nasional Penginderaan Jauh 2018:192-198

Penyusun T (2009) Bersahabat dengan Hutan Bakau: Restorasi Ekologis Hutan Mangrove, Hutan Lindung Angke Kapuk. Pantai Indah Kapuk, Sahabat Bakau

Permatasari PA, Setiawan Y, Khairiah RN, Effendi H (2016) The effect of land use change on water quality: a case study in Ciliwung watershed. IOP Conference Series: Earth and Environmental Science 54:012026. https://doi.org/10.1088/1755-1315/54/1/012026

Pomeroy RS, Ratner BD, Hall SJ, Pimoljinda J, Vivekanandan V (2006) Coping with disaster: rehabilitating coastal livelihoods and communities. Mar Policy 30:786-793. https://doi.org/ 10.1016/j.marpol.2006.02.003

Pontee N (2013) Defining coastal squeeze: a discussion. Ocean \& Coastal Management 84:204 207. https://doi.org/10.1016/j.ocecoaman.2013.07.010

Power WL (2013) Review of Tsunami Hazard in New Zealand (2013 Update), GNS Science Consultancy Report 2013/131. Retrieved March 13, 2021, from https://www.wremo.nz/assets/ Publications/Review-NZ-Tsunami-Hazard-2013.pdf

Purwoko PF, Wulandari AA, Benariva AP, Tiara A, Sabiel MQT, Risaandi R, Jannati A, Nugraha A, Noriko N, Priambodo TW (2016) Ketahanan Vegetasi Wilayah Mangrove Suaka Margasatwa Muara Angke. DKI Jakarta terhadap Sampah dari Aliran Sungai Seminar Nasional Perhimpunan Biologi Indonesia 2016:140

Putri L, Yulianda F, Wardiatno Y (2015) Pola zonasi mangrove dan asosiasi makrozoobentos di wilayah Pantai Indah Kapuk, Jakarta. Bonorowo Wetlands 5(1):29-43. https://doi.org/ 10.13057/bonorowo/w050104

Rahadian A, Leilan F, Arafat IN, Lestari TA (2019) Ecosystem mangrove management in urban area: case study mangrove Kali Adem Jakarta Indonesia. IOP Conference Series: Earth and Environmental Science 399:012008. https://doi.org/10.1088/1755-1315/399/1/012008

Sandilyan S, Kathiresan K (2015) Mangroves as bioshield: an undisputable fact. Ocean \& Coastal Management 103:94-96. https://doi.org/10.1016/j.ocecoaman.2014.11.011

Sasongko DA, Kusmana C, Ramadan H (2014) Strategi pengelolaan hutan lindung Angke Kapuk. Jurnal Pengelolaan Sumberdaya Alam dan Lingkungan 4(1):35-42. https://doi.org/10.19081/ jps1.2014.4.1.35

Sofian A, Kusmana C, Fauzi A, Rusdiana O (2020) Evaluasi Kondisi Ekosistem Mangrove Angke Kapuk Teluk Jakarta dan Konsekuensinya Terhadap Jasa Ekosistem. Jurnal Kelautan Nasional 15(1):1-12. https://doi.org/10.15578/jkn.v15i1.7722

Steinberg, F. (2007). Jakarta: environmental problems and sustainability. Habitat Int 31(3-4), 354 365. doi:https://doi.org/10.1016/j.habitatint.2007.06.002

Takagi H, Mikami T, Fujii D, Esteban M, Kurobe S (2016a) Mangrove forest against dyke-breakinduced tsunami on rapidly subsiding coasts. Nat Hazards Earth Syst Sci 16:1629-1638. https:/ /doi.org/10.5194/nhess-16-1629-2016

Takagi H, Esteban M, Mikami T, Fujii D (2016b) Projection of coastal floods in 2050 Jakarta. Urban Clim 17:135-145. https://doi.org/10.1016/j.uclim.2016.05.003

Takagi H (2017) Design considerations of artificial mangrove embankments for mitigating coastal floods - adapting to sea-level rise and long-term subsidence. Nat Hazards Earth Syst Sci. https:/ /doi.org/10.5194/nhess-2017-61

Takagi H (2019) "Adapted mangrove on hybrid platform" - coupling of ecological and engineering principles against coastal hazards. Results in Engineering 4:100067. https://doi.org/10.1016/ j.rineng.2019.100067

Tanaka N (2009) Vegetation bioshields for tsunami mitigation: review of effectiveness, limitations, construction, and sustainable management. Landsc Ecol Eng 5:71-79. https://doi.org/10.1007/ s11355-008-0058-z 
Tauhid FA, Zawani H (2018) Mitigating climate change related floods in urban poor areas: green infrastructure approach. Journal of Regional and City Planning 29(2):98-112. https://doi.org/ 10.5614/jrcp.2018.29.2.2

United Nations (2017) Factsheet: People and Oceans. Retrieved March 2, 2021, from https://www.un.org/sustainabledevelopment/wp-content/uploads/2017/05/Ocean-fact-sheetpackage.pdf

United Nations Development Programme (2004) Reducing disaster risk: a challenge for development. A global report. United Nations Development Programme, Bureau for Crisis Prevention and Recovery, New York. Retrieved March 1, 2021, from https://www.diplomacy.edu/reducingdisaster-risk-challenge-development

Unnikrishnan S, Singh A, Kharat MG (2013) The role of mangroves in disaster mitigation: a review. In: Filho WL (ed) Climate change and disaster risk management. Springer, Cham. https://doi.org/10.1007/978-3-642-31110-9_16

Wibowo K (2006) Pelestarian hutan mangrove melalui pendekatan mina hutan (silvofishery). Jurnal Teknologi Lingkungan 7(3):227-233. https://doi.org/10.29122/jtl.v7i3.386

Wijayanti P, Zhu X, Hellegers P, Budiyono Y, van Ierland EC (2017) Estimation of river flood damages in Jakarta, Indonesia. Nat Hazards 86:1059-1079. https://doi.org/10.1007/s11069016-2730-1

Winsemius HC, Jongman B, Veldkamp TIE, Hallegatte S, Bangalore M, Ward PJ (2018) Disaster risk, climate change, and poverty: assessing the global exposure of poor people to floods and droughts. Environ Dev Econ 23(3):328-348. https://doi.org/10.1017/S1355770X17000444

Wolanski E, Mazda Y, Ridd P (1992) Mangrove hydrodynamics. In: Robertson AI, Alongi DM (eds) Tropical mangrove ecosystems. American Geophysical Union, New York, pp 43-62. https://doi.org/10.1029/CE041p0043

Yanagisawa H, Koshimura S, Goto K, Miyagi T, Imamura F, Ruangrassamee A, Tanavud C (2009) The reduction effects of mangrove forest on a tsunami based on field surveys at Pakarang cape, Thailand and numerical analysis. Estuar Coast Shelf Sci 81:27-37. https://doi.org/10.1016/ j.ecss.2008.10.001

Yusuf AA, Francisco H (2009) Climate change vulnerability mapping for Southeast Asia. In: Economy and environment program for Southeast Asia. Retrieved March 8, 2021, from https:/ /www.preventionweb.net/files/7865_12324196651MappingReport1.pdf

Open Access This chapter is licensed under the terms of the Creative Commons Attribution 4.0 International License (http://creativecommons.org/licenses/by/4.0/), which permits use, sharing, adaptation, distribution and reproduction in any medium or format, as long as you give appropriate credit to the original author(s) and the source, provide a link to the Creative Commons license and indicate if changes were made.

The images or other third party material in this chapter are included in the chapter's Creative Commons license, unless indicated otherwise in a credit line to the material. If material is not included in the chapter's Creative Commons license and your intended use is not permitted by statutory regulation or exceeds the permitted use, you will need to obtain permission directly from the copyright holder.

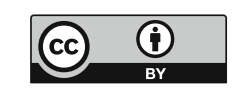

